\title{
ATYPICAL CONGENITAL HAEMOLYTIC ANAEMIA
}

BY

\author{
A. J. BRAFIELD and I. REEF \\ From Whipps Cross Hospital, London
}

(RECEIVED FOR PUBLICATION SEPTEMBER 26, 1956)

In recent years there has come to be recognized a group of haemolytic anaemias which are congenital and often familial, but in which the haematological findings are atypical. They cannot be classified with Cooley's anaemia or sickle cell anaemia or congenital spherocytosis. The group is heterogeneous and records of such cases are relatively few. Moreover the condition must be remembered in the differential diagnosis of neonatal jaundice. We therefore record the findings in two siblings one of whom presented as progressive pallor since birth, the other as neonatal jaundice.

\section{Case Reports}

Case 1. M.G. was referred to this hospital because of increasing pallor since birth. He was a first child, born of English parents on February 27, 1953. A greatgrandfather is said to have been Spanish. The pregnancy had not been entirely normal, the mother having developed signs of mild toxaemia for which labour was induced prematurely. The delivery was otherwise normal and the baby appeared healthy (weight $6 \mathrm{lb} .13 \mathrm{oz}$.).
On admission he was a very pale but otherwise healthy looking infant, aged 10 weeks, and weighing $10 \mathrm{lb}$. The liver was palpable two and a half fingerbreadths below the subcostal margin. The tip of the spleen could be felt at the level of the umbilicus. There were no other abnormal clinical signs. Radiographs of the entire skeleton revealed no abnormality. Haemoglobin was $32 \%(4.8 \mathrm{~g}$. per $100 \mathrm{ml}$.), reticulocytes $14 \%$, total leucocytes 18,000 per c.mm. (polymorphs $30 \%$, lymphocytes $61 \%$, monocytes $8 \%$, eosinophils $1 \%$ ). A stained film showed anisocytosis, polychromasia, nucleated red cells ( 30 per 100 leucocytes) and moderate numbers of target cells. Platelets appeared to be adequate. The serum bilirubin level was $0.9 \mathrm{mg}$. per $100 \mathrm{ml}$. A careful search for auto-antibodies in the infant's circulation yielded negative results. No incompatibility was found between the red cells of Mr. G. and the serum of Mrs. G. either in saline, or albumin, or after treatment with papain. Following a preliminary investigation of the bone marrow and erythrocyte osmotic fragility a blood transfusion was given. The subsequent course of the illness is shown in Fig. 1. Repeated transfusions were necessary to combat a rapidly developing anaemia, and ultimately, in Novem-

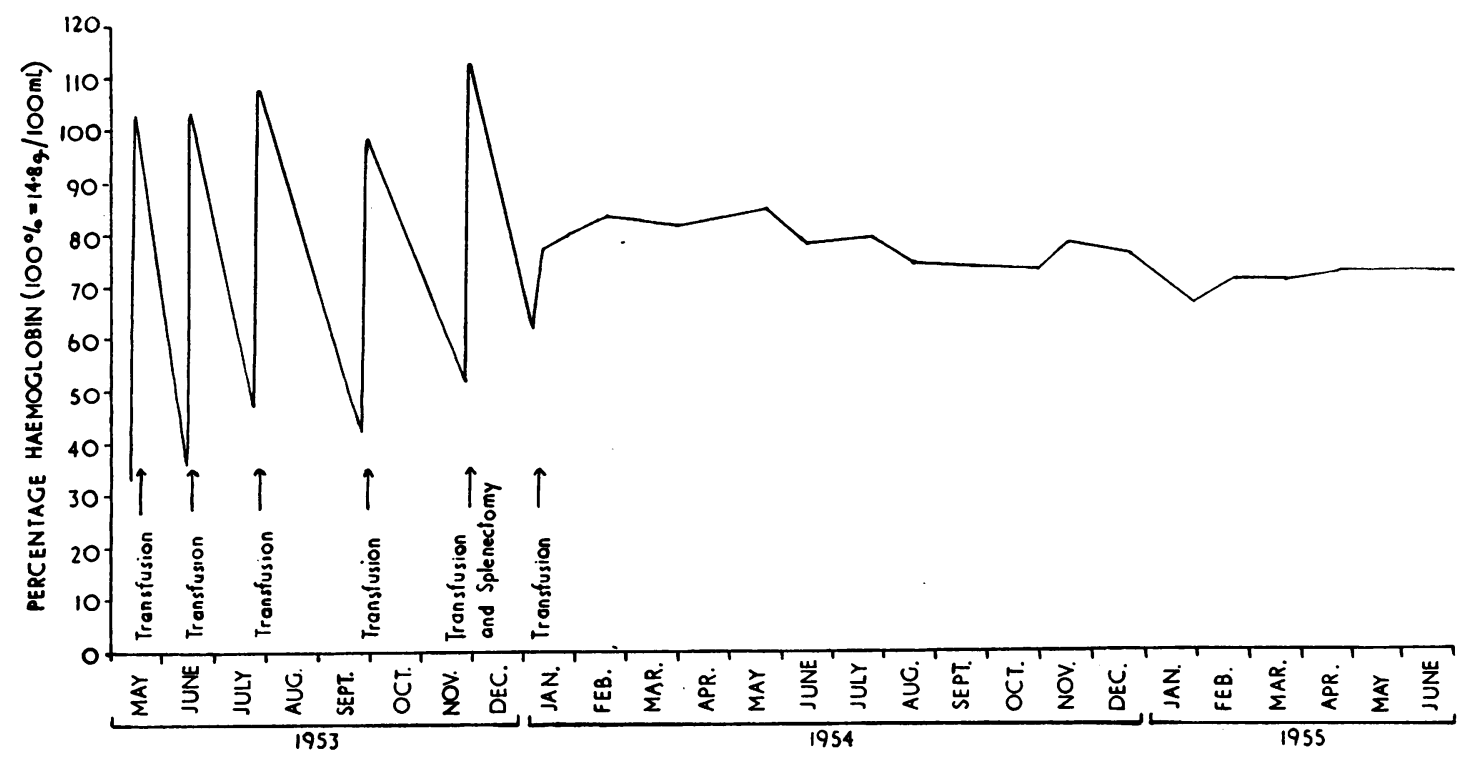

FIG. 1.-The chart shows the progress of the anaemia in the pre- and post-splenectomy periods in M.G. 
ber, 1953, the spleen was removed by Mr. Nardell. One month earlier, on October 23, 1953, the case had been presented at the Royal Society of Medicine (Paediatrics Section) and both splenectomy and cortisone were suggested as possible lines of treatment. When therefore the haemoglobin continued to fall after removal of the spleen, it was decided to give cortisone a trial. The dosage used was $100 \mathrm{mg}$. daily for one month, $50 \mathrm{mg}$. daily for the second month, $25 \mathrm{mg}$. daily for the next two weeks, and finally $12 \frac{1}{2} \mathrm{mg}$. daily for two weeks. There was some recovery during this period, the haemoglobin reaching $85 \%$ where it remained for some time. Later it settled to between $70 \%$ and $75 \%$, at which level it has remained without further transfusions.

Case 2. L.G., sister of M.G., was born on August 9, 1955, at the Mothers' Hospital, Clapton, under the care of Dr. Helen MacKay. A normal full-term pregnancy was followed by an uncomplicated delivery (birth weight, $6 \mathrm{lb} .6 \mathrm{oz}$.). Because it was known that the first child suffered from a form of haemolytic anaemia, the baby was closely observed and was noticed to be jaundiced four and a half hours after birth. Both liver and spleen

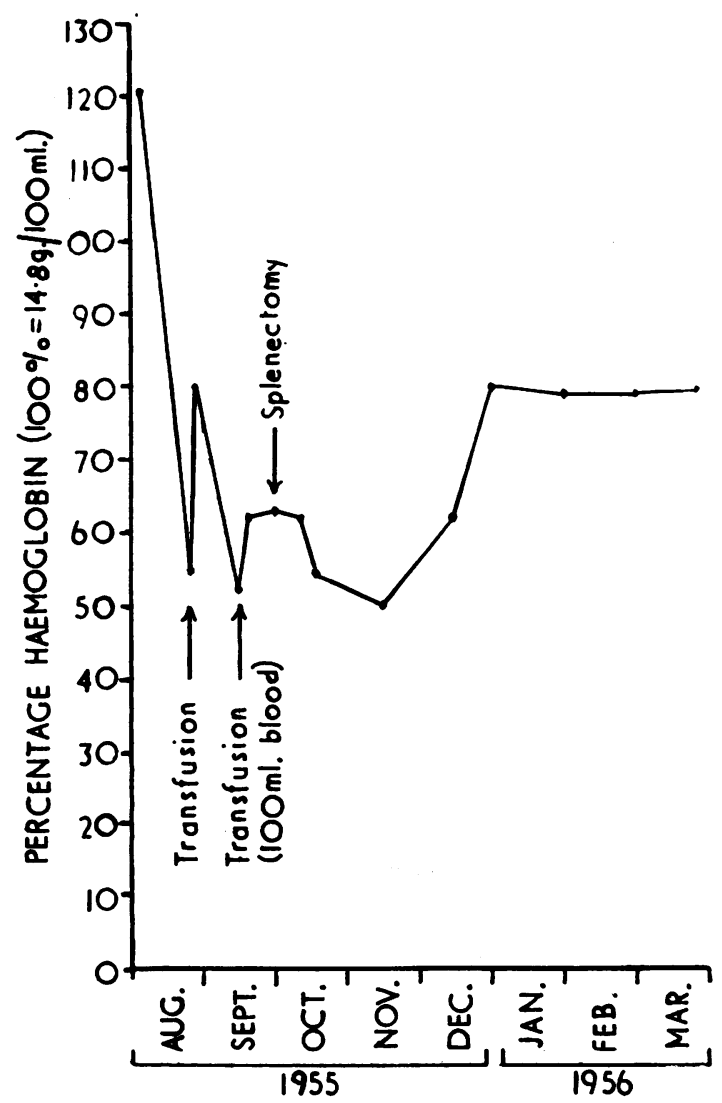

FIG. 2.-Progress of the anaemia in the case of L.G.9. The recovery of the haemoglobin level after splenectomy and in the absence of cortisone therapy is clearly shown. were palpable. At 18 hours the haemoglobin was $108 \%$ $(15.9$ g. per $100 \mathrm{ml}$.), leucocytes 24,000 per c.mm. (polymorphs $66 \%$, lymphocytes $26 \%$, monocytes $7 \%$, eosinophils $1 \%$ ), platelets 400,000 per c.mm. A stained film showed anisocytosis and much polychromasia. No target cells were seen. A reticulocyte count was not made at this stage though it was obviously raised. Nucleated red cells numbered 10,500 per c.mm. No abnormal cells were seen. The serum bilirubin level was $10 \mathrm{mg}$. per $100 \mathrm{ml}$. Her general condition was satisfactory and no active measures were taken. Two weeks later the child was seen at Whipps Cross Hospital. She was pale and lethargic. The liver and spleen were palpable. Haemoglobin was $54 \%(7.9 \mathrm{~g}$. per $100 \mathrm{ml}$.), reticulocytes $6 \cdot 1 \%$. A blood transfusion was given. One month later a second transfusion was necessary (Fig. 2) and it was decided to remove the spleen. This was done in October, 1955, by Mr. Nardell. After the operation the haemoglobin fell steadily, as in the case of the first child, but cortisone was withheld. On reaching $50 \%(7 \cdot 4 \mathrm{~g}$.) a vigorous spontaneous reticulocyte crisis occurred ( $24 \%$ on December 6$)$ and was followed by a rise in the haemoglobin to $70 \%$. It has remained at approximately this level ever since.

Recent radiographs of the skulls of both children appear normal.

\section{Special Investigations}

Bone Marrow. From M.G. a highly cellular marrow was obtained which showed an intense normoblastic response (L: $\mathrm{E}$ ratio $=0.54: 1)$. Leucopoiesis and platelet maturation were normal and no abnormal cells were seen. A single attempt to obtain a specimen from L.G. was unfortunately not very successful. Nucleated cells were scarce and no conclusion could be drawn.

M.C.D. Except for the first two weeks, the anaemia in both cases has been normocytic.

Osmotic Fragility. The method employed was that described by Dacie (1950). A stock phosphate-buffered solution is used, isotonic with $1 \%$ saline. Dilutions are made from this as required. Results are read colorimetrically.

In both infants repeatedly normal values were obtained both before and after incubation at $37^{\circ} \mathrm{C}$. for 24 hours (Fig. 3). The fragility was not significantly altered by splenectomy in the case of M.G., while only postsplenectomy studies were made on the second child.

Autohaemolysis. Autohaemolysis was investigated according to the method of Selwyn and Dacie (1954) using defibrinated blood, and the effect of adding glucose to the specimen before incubation was observed. Estimations of haemolysis were made at 24 and 48 hours. Values obtained were within the upper limit of normal, and the presence of glucose was without apparent effect. This contrasted with the normal controls in which the presence of glucose inhibited haemolysis to a marked degree.

Faecal Urobilinogen. Faecal urobilinogen was estimated in the post-splenectomy period only. Values of 
$371 \mathrm{mg}$. (M.G.) and $399 \mathrm{mg}$. (L.G.) per $100 \mathrm{~g}$. faeces were obtained.

Miscellaneous. Direct and indirect Coombs tests were negative. Sickling could not be induced. Electrophoresis failed to demonstrate any abnormal haemoglobins. The blood groups of the two infants and of

Histology of Spleens. Dr. C. Raeburn reports:

'M.G. Greatly thickened splenic cords with increased eight near relatives are shown in Table 1.

cellularity. Sinuses relatively empty. Malpighian bodies well defined with Fleming centres in some and fairly numerous mitotic figures. Plentiful free iron present. Slight myeloid infiltration. Very little erythrophagocytosis.'

'L.G. The appearances are similar but less severe and there is much less free iron.'

\section{Family Studies}

Eight other members of the family were investigated.

TABLE 1

BLOOD GROUPS OF THE G. FAMILY

\begin{tabular}{|c|c|c|c|c|c|c|c|c|c|c|c|}
\hline Name & ABO & $\underset{\text { Phenotype }}{\mathbf{R h}}$ & $\begin{array}{l}\text { Probable } \\
\text { Genotype }\end{array}$ & $\mathbf{M N}$ & $\mathbf{S}$ & $\mathbf{P}$ & $\mathbf{L u}$ & Kell & $\mathrm{Le}^{\mathrm{a}}$ & $\mathrm{Le}^{\mathbf{b}}$ & $F_{y}^{a}$ \\
\hline $\begin{array}{l}\text { M.G. } \\
\text { L.G. } \\
\text { H.G. } \\
\text { E.G. } \\
\text { J.B. } \\
\text { V.S. } \\
\text { A.G. } \\
\text { B.G. } \\
\text { F.R. } \\
\text { T.R. }\end{array}$ & $\begin{array}{l}\mathbf{A} \\
\mathbf{O} \\
\mathbf{A}_{1} \\
\mathbf{A}_{1} \\
\mathbf{A}_{1} \\
\mathbf{A}_{1} \\
\mathbf{O}_{1} \\
\mathbf{A}_{1} \\
\mathbf{A}_{1} \\
\mathbf{O}\end{array}$ & $\begin{array}{l}\text { CcDee } \\
\text { CcDee } \\
\text { CcDee } \\
\text { CcDee } \\
\text { CcDee } \\
\text { CcDee } \\
\text { CcDee }\end{array}$ & $\begin{array}{l}\text { 'Rh positive' } \\
\text { CDe/cde } \\
\text { CDe/cde } \\
\text { CDe/cde } \\
\text { CDe/cde } \\
\text { cde/cde } \\
\text { CDe/cde } \\
\text { cde/cde } \\
\text { CDe/cde } \\
\text { CDe/cde }\end{array}$ & $\begin{array}{l}\text { MN } \\
\text { MN } \\
\text { MN } \\
\text { MN } \\
\mathbf{N} \\
\text { MN } \\
\text { MN } \\
\text { MN } \\
\text { MN }\end{array}$ & $\begin{array}{l}+ \\
- \\
+ \\
- \\
- \\
+ \\
+\end{array}$ & $\begin{array}{c}+t+ \\
\bar{t}+ \\
+ \\
+t+ \\
+ \\
+\bar{t} \\
++t\end{array}$ & $\begin{array}{l}- \\
- \\
- \\
- \\
- \\
- \\
-\end{array}$ & $\begin{array}{l}- \\
- \\
- \\
- \\
- \\
- \\
-\end{array}$ & $\begin{array}{l}+ \\
- \\
- \\
- \\
- \\
- \\
-\end{array}$ & $\begin{array}{l}\overline{+} \\
+ \\
\overline{+} \\
+ \\
+ \\
+ \\
+\end{array}$ & $\begin{array}{l}+ \\
+ \\
+ \\
- \\
+ \\
+ \\
+ \\
+\end{array}$ \\
\hline
\end{tabular}

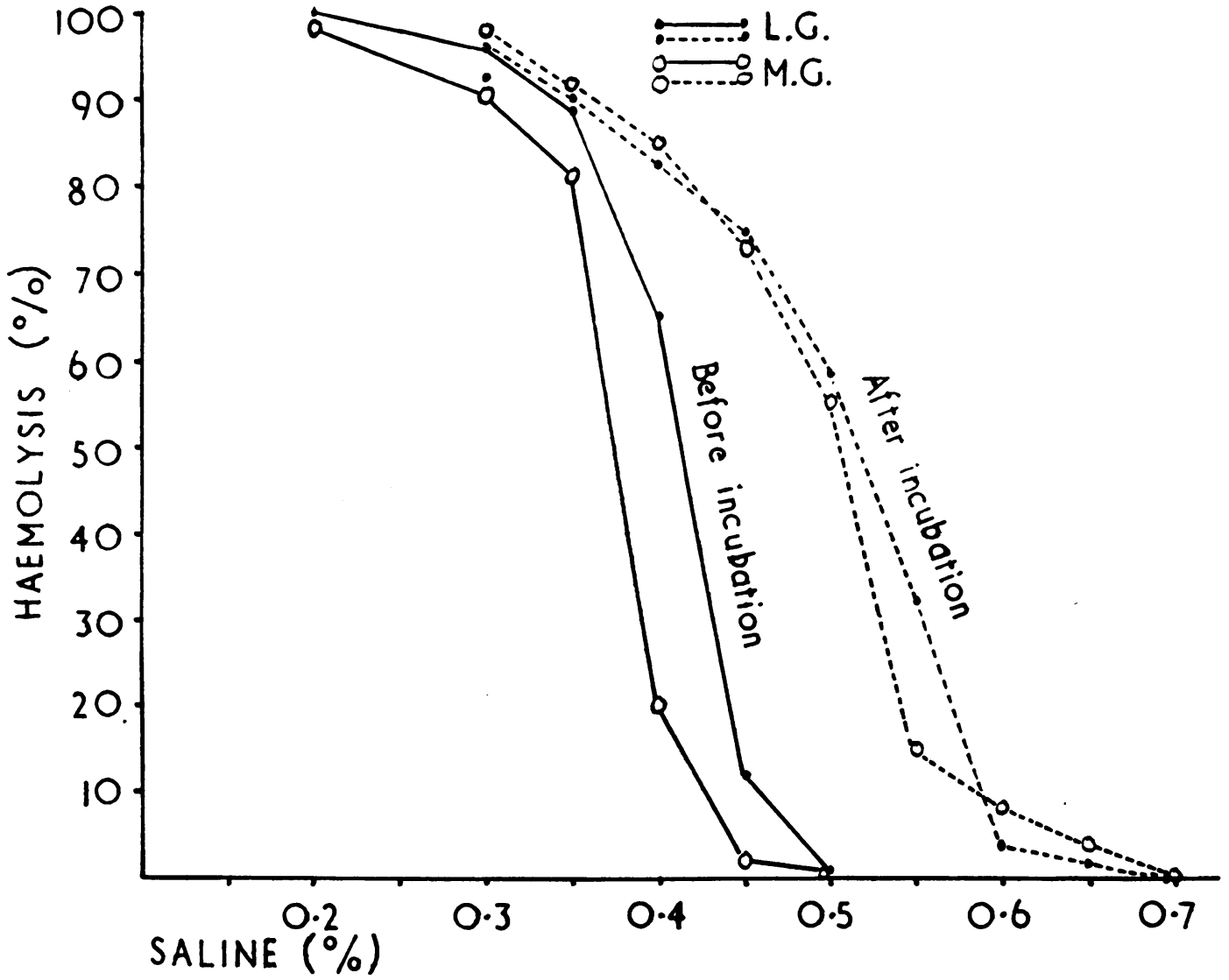

FIG. 3.-Osmotic fragility before and"after incubation of the blood for 24 hours at $37^{\circ} \mathrm{C}$ in M.G. and L.G. 
Their relationship is shown in Fig. 4. The following tests were carried out: Haemoglobin content, red cell and reticulocyte counts, examination of stained films of peripheral blood, Wassermann and Kahn tests, quantitative estimations of erythrocyte osmotic fragility both before and after incubation for 24 hours at $37^{\circ} \mathrm{C}$., and all results were normal.

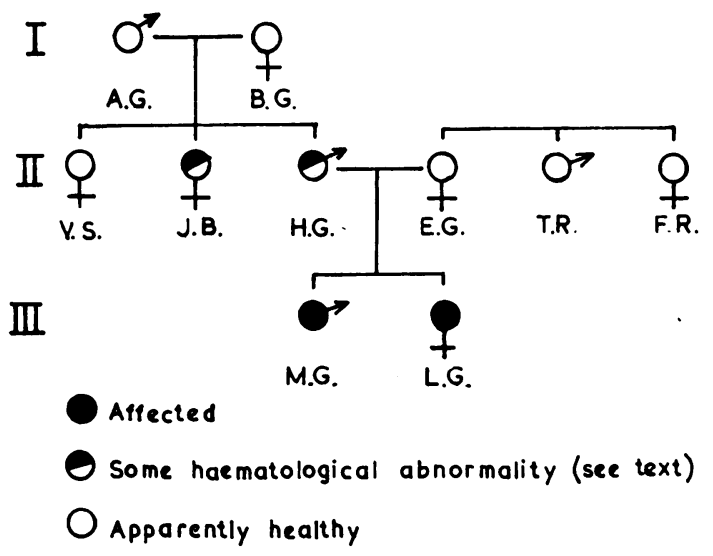

FIG. 4.-The G. family indicating the relationship of the persons listed in Table 1.

Studies of autohaemolysis also produced normal results except in one instance in which a paternal aunt (J.B.) showed $1.04 \%$ haemolysis at 48 hours which was unaffected by the presence of glucose. This finding was confirmed on a second occasion.

Estimations of serum bilirubin revealed normal values in all relatives except the father (H.G.). His family had noticed for many years that he was 'sometimes yellow', though he himself was unaware of any accompanying discomfort. His serum was unduly yellow to the naked eye and three estimations repeated at long intervals gave values between 1.2 and $1.5 \mathrm{mg}$. per $100 \mathrm{ml}$. Additional investigations in his case included electrophoresis of haemoglobin, total and differential serum proteins, a battery of liver function tests (alkaline phosphatase, thymol turbidity, cephaline cholesterol, zinc sulphate, Takata-Ara), and examination of urine for haemosiderin granules. All results were normal. A single estimation of faecal urobilinogen gave a result of $127 \mathrm{mg}$. per $100 \mathrm{~g}$. faeces.

\section{Discussion}

The congenital haemolytic anaemias now comprise at least five distinct groups:

(a) Thalassemia (Cooley's anaemia) is characterized by a hypochromic anaemia which is refractory to iron, the presence of 'target' cells, a greatly decreased osmotic fragility and a pronounced racial incidence.

(b) Congenital spherocytosis (acholuric jaundice) in which microspherocytes are demonstrable in the peripheral blood, the osmotic fragility is increased, and the results of splenectomy are excellent.

(c) Hereditary elliptocytosis with haemolytic anaemia.

(d) The 'haemoglobinopathies' are almost confined to negroid races. The haemolytic anaemia may be of any grade of severity and is associated with the presence in the erythrocytes of an abnormal haemoglobin which is usually recognized by electrophoresis. The best known of this group is sickle cell anaemia.

(e) A miscellaneous group of atypical haemolytic anaemias.

It is with this last group that we are concerned. Thompson (1939) described a haemolytic anaemia in three families which exhibited certain unusual features. Erythrocyte morphology was normal and the cells could not be induced to sickle. Osmotic fragility was normal and splenectomy was valueless. Similar reports followed, the majority from America (Haden, 1947; Crosby, 1950; Kaplan and Zuelzer, 1950; Feinberg and Watson, 1951; Holliday, 1953; Lipton, Grossman and Richmond, 1953; Dacie, Mollison, Richardson, Selwyn and Shapiro, 1953; Motulsky, Crosby and Rappaport, 1954; Smiley, Dempsey, Villeneuve and Campbell, 1955), but it is clear that they are not all concerned with a single disease entity. For the purpose of classifying these anaemias certain common features are notable: (1) They are congenital and often familial. (2) Red cell morphology is normal and sickling cannot be induced. (3) Osmotic fragility of the erythrocytes is normal. (4) Splenectomy does not cure the disease. In addition basophilic stippling of the red cells has been conspicuous in some instances, and many of the anaemias have been macrocytic.

Not all these features are to be found together in any particular case, and their common factor is rather their exclusion from the other well defined categories. Dacie (1954) groups them together under the title 'Congenital Non-spherocytic Haemolytic Anaemias'. Selwyn and Dacie (1954) have divided their own cases into two types based on a major difference in behaviour on incubation of the patient's blood. Some of the methods they have used are complicated and are unlikely to become part of routine practice in the average hospital laboratory. The simplest of these measures is a study of autohaemolysis. By this means congenital spherocytosis can be differentiated from the nonspherocytic anaemias, and in addition a distinction may be made between the two types of the latter (Table 2).

In type $I$ autohaemolysis is normal while in 
TABLE 2

AUTOHAEMOLYSIS IN THE DIFFERENTIATION OF CONGENITAL HAEMOLYTIC ANAEMIAS (AFTER SELWYN AND DACIE)

\begin{tabular}{c|l|l}
\hline Normal & $\begin{array}{c}\text { Autohaemolysis } \\
\text { at 48 Hours }\end{array}$ & $\begin{array}{c}\text { Effect of Added } \\
\text { Glucose }\end{array}$ \\
\hline $0.4 \%$ to $3 \cdot 5 \%$ & $\begin{array}{l}\text { Marked inhibition- } \\
\text { to less than 0.2\% } \\
\text { Congenital spherocytosis }\end{array}$ & $\begin{array}{l}\text { Greatly increased } \\
\text { Prounced reduction } \\
\text { of haemolysis but } \\
\text { still above normal }\end{array}$ \\
$\begin{array}{c}\text { Congenital non-sphero- } \\
\text { cytic haemolytic anaemia } \\
\text { Type I } \\
\text { Type II }\end{array}$ & $\begin{array}{l}\text { Normal } \\
\text { Increased }\end{array}$ & No effect \\
\hline
\end{tabular}

type II it is increased. In neither case has the addition of glucose any appreciable effect on haemolysis.

The results of such tests applied to the cases described here suggest a close relationship with Selwyn and Dacie's type I. The haemolytic nature is borne out by the jaundice, the rapidly falling haemoglobin associated with a hyperplastic bone marrow and raised reticulocyte counts, and the increased excretion of faecal urobilinogen. Osmotic fragility is normal in both cases. No abnormal cells are present apart from the few target cells in the peripheral blood of M.G. Sickling cannot be induced. No abnormal haemoglobins are demonstrable. Autohaemolysis at 48 hours was within normal limits, and the addition of glucose to the blood was without effect.

The histology of the spleens conforms with the diagnosis of a non-spherocytic haemolytic anaemia. Motulsky et al. (1954) drew attention to the differences to be observed microscopically in the spleens from spherocytic and non-spherocytic haemolytic anaemias. They noted particularly the absence of congestion of the pulp cords in the latter and stated that

‘. a comparison of the splenic histologic findings in the two conditions suggests an explanation for the variation in response to splenectomy. The splenic pulp in hereditary spherocytosis is markedly congested with spherocytes ... Removal of the spleen allows the spherocytes to live a normal life-span and the disease is cured. Failure to respond to splenectomy in hereditary nonspherocytic haemolytic disease may be related to the lack of congestion which can be explained by the normal shape of the affected red cells. No selective trapping occurs. After splenectomy the defective erythrocytes continue to be destroyed prematurely even in the absence of the spleen.'

In our cases splenectomy has not cured the disease but has apparently produced a worthwhile palliative effect. Neither child has required further transfusions and the haemoglobin level has been main- tained, though at a sub-optimal level. The raised reticulocyte counts and the excessive excretion of faecal urobilinogen indicate the continuance of the haemolytic process. The two cases described by Kaplan and Zuelzer (1950) also received some benefit from splenectomy, but in contrast with those described in this paper, they both exhibited a raised osmotic fragility before operation. Such cases can expect some measure of relief when the spleen is removed. The cases of Lipton et al. (1953), however, showed a normal resistance to saline, yet were benefited by splenectomy.

Cortisone is not normally of any value in the management of congenital haemolytic anaemias and it is very doubtful whether it conferred any benefit when used on the elder child, since the younger improved spontaneously in exactly similar circumstances.

The question of inheritance in these cases is problematical. It is of interest that the only abnormal findings among members of the family, viz., the abnormal autohaemolysis in J.B. and the raised serum bilirubin in H.G., occur on the same side of the family tree, and it appears likely that the corpuscular defect manifest in the infants has been transmitted via the father. Dameshek and Singer (1941) have reported under the title 'Familial Haemolytic Jaundice: Constitutional Hepatic Dysfunction' instances of persistently raised serum bilirubin levels in families in which there was no evidence of haematological or hepatic dysfunction. H.G. presents just such a case, and it is probable that such patients are, in fact, instances of congenital non-spherocytic haemolytic anaemia.

\section{Summary}

Two cases of congenital haemolytic anaemia are recorded, the first presenting as increasing pallor since birth, the second as neonatal jaundice.

The clinical and haematological findings in both cases suggested haemolytic disease, though the nature of the haemolytic process was not at first evident.

The haematological observations upon which the final diagnosis is based are given in detail and particular attention is directed to the study of autohaemolysis as a means of differentiating congenital spherocytosis from the non-spherocytic haemolytic anaemias.

Splenectomy was beneficial to the extent of obviating the necessity for further blood transfusions though it did not halt the haemolytic process.

Family studies suggested that the defect was present in and transmitted by the father. 
The diagnosis and modern classification of congenital haemolytic anaemias is discussed with special reference to the 'non-spherocytic group', recorded examples of which are still relatively few.

We wish to thank Dr. C. Raeburn for the histological reports, Dr. W. W. Walther for reading the final manuscript and for advice thereon, Dr. Helen MacKay, of the Mothers' Hospital, Clapton, for the initial observations on L.G., Dr. C. Hinden for advice and for permission to publish the cases, Dr. A. E. Mourant for the genotyping and Mr. John Case for much of the technical work.

\section{REFERENCES}

Crosby, W. H. (1950). Blood, 5, 233

Dacie, J. V. (1950). Practical Haematology. London. (1954). The Haemolytic Anaemias. London.

, Mollison, P. L., Richardson, N., Selwyn, J. G. and Shapiro, L. (1953). Quart. J. Med., 22, 79.

Dameshek, W. and Singer, K. (1941). Arch. intern. Med., 67, 259.

Feinberg, A. W. and Watson, J. (1951). Blood, 6, 357.

Haden, R. L. (1947). Amer. J. med. Sci., 214, 255.

Holliday, T. D. S. (1953). J. clin. Path., 6, 219.

Kaplan, E. and Zuelzer, W. W. (1950). Blood, 5, 811.

Lipton, E. L., Grossman, H. J. and Richmond, J. B. (1953) Pediatrics, 12, 384.

Motulsky, A. G., Crosby, W. H. and Rappaport, H. (1954). Blood, 9, 749 .

Selwyn, J. G. and Dacie, J. V. (1954). Ibid., 9, 414 Smiley, R. K., Dempsey, H., Villeneuve, P. and Campbell, J. S.

Thompson, W. P. (1939). Bull. N.Y. Acad. Med., 15, 177. 